\title{
Positive and Negative Lexical Transfer in English Vocabulary Acquisition
}

\begin{abstract}
The aim of the paper is to explore the appearance of positive and negative lexical transfer of plurilingual learners in English vocabulary acquisition. Cross-linguistic influences in the study are examined by word translation tasks from Croatian into English, including true, partial, and deceptive cognates or false friends in English, German, and Italian. The results have revealed different language dominances and positive or negative transfer manifestation. Lexical transfer from L4 German is manifested positively, but the Italian language seems to play a dominant role in the acquisition of English vocabulary. The effect of Croatian is manifested both positively and negatively. The study has confirmed previous psycholinguistic studies on the complexity of lexical connections in plurilingual learners and the dynamic interaction of various learningbased factors, such as language recency, proficiency, exposure to languages, the order in which languages are learned, and the formal context in language learning.
\end{abstract}

Keywords: English vocabulary acquisition, language dominance, plurilingual learners, positive and negative lexical transfer

\section{Pozitivni in negativni leksikalni transfer pri usvajanju angleškega besedišča}

\section{IZVLEČEK}

Namen prispevka je raziskati pojav pozitivnega in negativnega leksikalnega transferja večjezičnih učencev pri usvajanju angleškega besedišča. V študiji preučujemo medjezikovne vplive $\mathrm{z}$ nalogami prevajanja besed iz hrvaščine $\mathrm{v}$ angleščino, ki vključujejo tudi resnične, delne in zavajajoče sorodnike ali lažne prijatelje $v$ angleščini, nemščini in italijanščini. Rezultati so razkrili različne jezikovne prevlade ter pozitivne ali negativne pojave transferja. Leksikalni transfer iz nemščine kot četrtega jezika se kaže kot pozitiven, vendar se zdi, da ima italijanski jezik prevladujočo vlogo pri usvajanju angleškega besedišča. Učinek hrvaščine je tako pozitiven kot negativen. Študija je potrdila prejšnje psiholingvistične študije o kompleksnosti leksikalnih povezav pri večjezičnih učencih, kakor tudi dinamično interakcijo različnih dejavnikov, ki temeljijo na učenju: jezikovna nedavnost, znanje, izpostavljenost jezikom, vrstni red, v katerem se jeziki naučijo, in formalni kontekst učenja jezika.

Ključne besede: usvajanje angleškega besedišča, jezikovna prevlada, večjezični učenci, pozitivni in negativni leksikalni transfer 


\section{Introduction}

Language transfer is a phenomenon in second language acquisition research which refers to the transfer of language units from one language system into another. As a phenomenon it started to gain attention with the occurrence of contrastive analysis, a methodological approach in language theory in the 1960s, whose main aim was to compare compound structures in the first and second languages in order to reveal similarities or differences between the two language systems. It was assumed that on the basis of analysed similarities or differences between the two languages and through the production of well-created pedagogical materials, learners might overcome transfer in the second language production, which was usually reflected from their first language. Thus, the importance of language transfer is seen in explaining the nature of foreign language learners' errors, as well as in finding the main source of transfer.

Likewise, language transfer is one of the indicators of successful foreign language learning. There are two well-known classifications of language transfer - positive and negative transfer. Negative language transfer is defined as the influence of differences from the first language (or even any other language, regardless of the order of learning it) on the target language, which then cause learner errors in the target language production. Bardovi-Harlig and Sprouse $(2017,1)$ explain that positive language transfer occurs "when the influence of the native language leads to immediate or rapid acquisition or use of the target language". Both positive and negative transfer present crucial issues in the foreign language teaching.

Until recently, the most common issue in language transfer that has been discussed in the literature is that of transfer between two language systems. Moreover, investigations of language transfer within the domain of multilingualism have been growing rapidly in the last two decades (Bouvy 2000; Ilomaki 2005; Tymczyńska 2012; Peukert 2015; Pfenninger and Singleton 2016). The main goal of this paper is thus to examine the appearance of positive and negative lexical transfer in Croatian learners of English, German and Italian and show the manifestations of transfer in English vocabulary acquisition.

The structure of the paper is as follows: section 2 provides the theoretical background of the study, focusing on lexical transfer in multiple language acquisition and lexical transfer studies from various perspectives. Section 3 presents the aim and hypotheses of the study, while section 4 deals with its methodology, including the participants, assessments and measures, procedure and data analysis. Section 5 shows the results of the study and discusses the appearance of positive and negative lexical transfer from German, Italian and Croatian into English. The paper is concluded in section 6, in which glottodidactic implications for the English language classroom are presented.

\section{Literature Review}

\subsection{Lexical Transfer in Multiple Language Acquisition}

Lexical transfer in multiple language acquisition has been the focus of an increasing number of studies (Lindqvist 2009; Burton 2012; Woll 2016; Ortega and Luz Celaya 2019; Efeoglu, 
Yüksel, and Baran 2020), but it still represents an underexplored phenomenon in foreign language teaching.

De Angelis $(2007,41)$ explains that "non-native linguistic influence is particularly visible in the area of lexis, where traces of non-target information are mostly overt and therefore easily recognizable". Lexical transfer is defined as "the influence of word knowledge in one language on a person's knowledge or use of words in another language" (Jarvis and Pavlenko 2008, 72). According to De Angelis $(2007,44)$, "from a multilingual perspective, the transfer can occur from the $\mathrm{L} 1$ as well as the non-native languages, which means that the native language does not always have a privileged status and must be looked at together with other possible sources of transfer." Additionally, the distinction of lexical transfer between two language systems (L1 and L2) and lexical transfer between more than two language systems (L1, L2, L3, L4, etc.) has to be made. The lexical transfer between L1 and L2 is usually bidirectional, which means that an L1 word can influence L2 word and vice versa, while lexical transfer between multiple language systems is multidirectional, and it can take place between L1 and L3, L2 and L3, L3, L4, and so on, in all possible directions.

Jarvis and Pavlenko (2008, 74-75) divide lexical transfer into three broad categories: transfer related to morphophonological (e.g., "the use of false cognates" - Eng. fabric - Ger. Fabrik; "unintentional lexical borrowing involving the use of a word from the wrong language"; "the coinage of a new word by blending two or more words from different languages") and semantic errors (e.g., "the use of an authentic target-language word with a meaning that reflects influence from the semantic range of a corresponding word in another language" - like in transfer from Finnish to English: He bit himself in the language, instead of tongue; "the use of a calque in the target language that reflects the way a multi-word unit is mapped to meaning in another language"); cross-linguistic influence effects related to lexical representation, accessibility, and activation (e.g., "when a word is acquired in new language it might become mentally associated with a word in an already-known language in multiple ways" - phonologically, grammatically, conceptually); and word choice transfer - a phenomenon that involves several dimensions of word knowledge simultaneously (e.g., L2 users may choose in English "an adjective happy instead of an intransitive verb to rejoice to refer to someone's emotions"). The lexical transfer that is analysed in our study is the transfer related to morphophonological and semantic errors including different types of cognates, which will be further explained in the paper (section 2.3).

Recent studies of lexical transfer place their methodology in spoken and written discourse, formal and informal environments, having in mind both psycholinguistic and sociolinguistic aspects of bilingualism and multilingualism. The following section gives a brief overview of lexical transfer studies in multiple language acquisition from various perspectives, which are of relevance for our study.

\subsection{Studies of Lexical Transfer}

Boratyńska-Sumara (2014) claims that "transfer of form and transfer of meaning, as well as transfer of content (lexical open-class words) and function words (lexical closed-class words) have been major issue in transfer studies". Examining transfer from the perspective of 
intentionality and unintentionality, Boratyńska-Sumara $(2014,138)$ points out that “identifying intentional transfer with cross-linguistic influence as a conscious communicative strategy and unintentional transfer with making interlingual mental associations and identifications, is a simplification of a very complex phenomenon". Along with this, the author mentions that "the main area of research in a European context is linguistic, forward and lateral lexical interlingual transfer which is not seen from the perspective of intentionality and whether it is positive or negative" (Boratyńska-Sumara 2014, 147). In line with Boratyńska-Sumara’s claim (2014) on intentionality and unintentionality of transfer, Fuster and Neuser (2020) have also explored the extent to which lexical transfer in written production is intentional or unintentional. According to the authors, transfer is intentional if learners are conscious of their transferred items and can comment on the items. In contrast, transfer is unintentional if the learners are not aware of their transferred items. The participants in Fuster and Neuser (2020) were multilingual learners, three native speakers of Swedish and one native speaker of Norwegian with typologically related and unrelated second languages (English, Spanish, Danish, German, French, Portuguese, Italian, Hungarian, Arabic, Swahili). In order to determine whether the instances of transfer occurred intentionally or unintentionally, the written picture description task was used along with the think-aloud protocol and stimulated recall. The intentionality of transfer was predominantly expressed in semantic types of transfer and typologically distant learners' languages, while as an unintentional mechanism transfer could be found in transfer of form, typologically close languages and function words. The issue of the intentionality and unintentionality of lexical transfer studies may be considered from the perspective of positive and negative transfer that is examined in our study, as the methodology used in the current work is aimed at examining types of transfer from all learners' languages (L1, L2/L3, L4) to L2/L3 English regardless of the order of learning them.

Noteworthy is the study of Perić and Novak Mijić (2017), who examined the cross-linguistic influences of learners with L1 Croatian and L2 English in L3 Spanish and the relationship between language proficiency and types of lexical errors. Perić and Novak Mijić (2017) assumed that L2 English would be the main source of both transfer types - transfer of form and transfer of meaning because of formal similarity between English and Spanish, and that with the higher level of proficiency the production of errors would be reduced and the type of lexical errors would be changed. The analysis of compositions written by second- and third-year students during their final exam at the faculty, showed that "with the increase of L3 proficiency, lexical transfer changed, and the influence of L1/L2 decreased" (Perić and Novak Mijić 2017, 102). Therefore, the mentioned study has confirmed the results of other studies (Burton 2012; Lindqvist and Bardel 2013; Pinto 2013; Bardel 2015) that indicated that proficiency in both the target and source language was one of the key factors in observing and determining lexical transfer.

Apart from language proficiency, other important learning-based factors in examining transfer are recency of use and order of language acquisition. A well-known case study that evoked recency as one of the determining factors in participant's L3 production is that of Williams and Hammarberg (1998). The authors claimed that L2 German was more activated due to its recent use, and thus they considered L2 German as the main language supplier in L3 Swedish production (Williams and Hammarberg 1998). 
Dewaele (1998) conducted a study on lexical inventions produced by speakers of L1 Dutch in L2 and L3 French production. The author stated that "the active language with the highest level of activation was the preferred source of lexical information and L1 was not necessarily always the dominant active language, therefore access to its lemmas could be limited" (Dewaele 1998, 488). Accordingly, the order of acquisition and language activation may determine the type and amount of language transfer in the target language.

Although previous studies have focused on psycholinguistic aspects of multiple language acquisition, it is also essential to mention one study on the sociolinguistic aspect of bilingualism by Makarova Tominec (2015), who examined language contacts in Russian-Slovenian bilinguals at the orthographic, phonological, morphophonological and lexical levels. The participants were second-generation Russian-speaking residents of Slovenia. The results showed several types of influence of the Slovenian language as a functionally dominant language in the Russian language production, as seen in interference at different language levels, simplification and underproduction. The dominance of Slovenian could be explained by the fact that it was the language of the environment, and as the participants were young (ages 15-30 years; $\mathrm{N}=24$ ) and middle-aged adults (ages $40-55$ years; $N=3$ ) they had easily integrated into Slovenia, not only with regard to the language, but the culture, too. Therefore, the study demonstrated the great complexity in examining language transfer entailing both psycholinguistic and sociolinguistic aspects of bilingualism and multilingualism. One of the psycholinguistic aspects, which is also reflected in the present study, is the exploration of lexical transfer with respect to the dominance of background languages in English vocabulary acquisition.

\subsection{Lexical Transfer Studies from a Methodological Perspective}

Studies of multiple language acquisition have shown a diverse methodology in the examination of lexical transfer. According to Jarvis $(2009,118)$, the more controlled methods include picture naming (e.g., seeing a picture of a bear and saying bear), picture classification (e.g., deciding whether various pictures represent things that are human-made versus natural), word naming (e.g., seeing the word bear and pronouncing it aloud), word translation (e.g., seeing bear and translating it into another language), lexical decision (e.g., deciding whether uncle refers to a male or female, deciding whether problem and question are similar), and various types of lexical preference tasks (e.g., multiple-choice tasks, fill-in-the-blank tasks), as well as grammaticality judgement tasks (e.g., where an individual word or a multiword unit may be of the wrong form or carry the wrong meaning). The less controlled methods refer to free and spontaneous production tasks, such as "oral interviews, written essays, oral and written narrative descriptions of pictures and silent films" (Jarvis 2009, 119). For the purpose of our study two different word translation tasks were used as more controlled methods due to the assumption that these translation tasks would trigger more cognate activation in learners' background languages in English language production.

Nevertheless, the words that have been mostly used by researchers are cognates. Cognates are defined as words of the same or similar form and meaning in two or more languages. In the studies of psycholinguistic aspects of multilingualism, several types of cognates are distinguished, such as true, partial and deceptive cognates. True cognates denote words in two 
or more languages, which are usually etymologically related; they are of similar orthography and pronunciation, and of the same meaning. Partial cognates refer to words whose semantic properties partially overlap, and often share similar orthography and pronunciation in the languages. Deceptive cognates are mostly referred to as false friends, denoting the words with similar or the same orthography and pronunciation, but with different meaning, and these are often used in elicitation tasks.

For the analysis of cognates in our study we decided to use the word translation method, which can be a good indicator of "the real nature of students' multicompetence and interlanguage, as well as the mechanics of cross-linguistic interaction" (Latkowska 2006). To date, there have been plenty of lexical transfer studies with different first and second languages of the students that have used various translation methods, like written text translations (Bouvy 2000; Gabryś 2000; Herwig 2001; Gibson and Hufeisen 2003; Ilomaki 2005; GabryśBarker 2006), written translations of decontextualized words (Ecke 2001; De Angelis 2005), oral translations of sentences (Letica and Mardešić 2007), oral translations of individual words (Pál 2000; Kujalowicz and Zajdler 2009; Tkachenko 2011), often combined with other methods, such as tip-of-the-tongue state (Ecke 2001), think aloud verbal protocols (Herwig 2001; Gabryś-Barker 2006), retrospection (Gibson and Hufeisen 2003), and a picture description task (Letica and Mardešić 2007).

With reference to Ravem (1986), Larsen-Freeman and Long $(1991,80)$ state that "the use of translation as an elicited procedure, requires both the decoding of the stimulus sentence and the encoding of the translation, so that subjects' performance approximates natural speech production".

Similarly, the method in the present study was developed based on the translation methods of Ecke (2001) and De Angelis (2005), who used written word translations. Ecke (2001) used both a word translation task and tip-of-the-tongue states in order to investigate lexical retrieval in L3. The participants were beginning learners of German as L3 with L1 Spanish and an intermediate-high proficiency level of L2 English. The translation task contained a stimulus of the Spanish translation equivalent and a brief sentence context in L3 German with the target word left blank (see Ecke 2001, 108). The study revealed that the degree of L1, L2 and L3 influence varied according to processing tasks and conditions. In other words, errors in the word-translation task mainly reflected unintended, automatic retrieval failures, which were, as explained by Ecke (2001), mostly due to the influence of connected L2 structures that could not be suppressed, since the words used in the study were cognate equivalents in L1, L2 and L3. On the other side, the tip-of-the-tongue states primarily involved extensive, conscious word search within the L3 (partially due to the suppression of L2 and L1 influence) (Ecke 2001, 106). Notably, the word translation method in Ecke's study (2001) clearly indicated activation of all the languages during extensive word search.

The word translation method, slightly different from the method in the previous study by Ecke (2001), was used in one of the studies presented by De Angelis (2005). De Angelis (2005) investigated cognitive processes in the non-native languages of L1 English learners of L2 Spanish and L3 Italian. The learners had to translate the written decontextualized words from English into Italian and then from English into Spanish. The words were non-cognates 
across the three languages. The results showed that the learners often used the same Spanish or Italian word for both translation tasks, which suggested "the use of borrowing strategies in order to fill knowledge gaps in the target language" (De Angelis 2005, 7). In contrast to De Angelis (2005), the aim of the present study was different in the examined languages, as well as in the use of words (see section 4.2)

Furthermore, in the context of multiple language acquisition, the main focus has been on the interactions between two or more non-native languages, rather than the learner's native language.

Sercu (2007) investigated the activation of multiple foreign languages acquired by secondary school learners while translating a text from their mother tongue into different foreign languages (Dutch, French, English, German). The research questions were whether learners managed to keep their languages apart during translation, to which language they resorted in case of cross-linguistic influence, whether loanwords occurred more frequently than loanblends or literal translations, and to what extent variables such as psychotypology and psychoproficiency affected target language production. The data showed that both first language and other foreign languages were activated in learners' multilingual lexicon. At the same time, "the better-mastered foreign languages were used as sources of help when confronted with a lexical gap, whereas less well-mastered languages caused cross-linguistic errors in better-mastered languages" (Sercu 2007, 70). What is confirmed by this study is a reactive control mechanism, which refers to the following process: "where individuals are consistently translating from one direction to another, the controlling schema is in place and the extent of cross-linguistic influence will probably be limited" (Sercu 2007, 57). As discussed by Sercu $(2007,56)$, it was because both "the contextually appropriate and the contextually inappropriate memory nodes were available in translation, requiring active suppression of the latter, which leads to a rather complex mental process". We decided to conclude this section with Sercu's statement because our study attempts to explain various activations of the languages in examining English vocabulary production, regardless of learners' proficiency in all the languages.

\section{Aim and Hypotheses}

The aim of the study was to explore the appearance of positive and negative lexical transfer in plurilingual learners and present the dominance of the languages in English vocabulary acquisition.

The hypotheses were as follows:

H1: There would be more negative than positive transfer from German, that is, the German language would be closely connected with the appearance of negative transfer in English vocabulary production because learners' were at the beginner's level of learning German, thus it was assumed that proficiency in German was lower compared to that in other languages and would cause more negative influence.

H2: There would be less negative transfer from Italian, that is, the Italian language would not be closely connected with the appearance of negative transfer but it would 
be more related to the appearance of positive transfer as years of learning Italian, the exposure to the language, and thus supposedly better language proficiency in the language, would cause less negative influence from Italian.

H3: Croatian as L1 would not show a significant relationship with the appearance of either positive and negative transfer in English, as it was typologically unrelated to L2/ L3 English. On the other hand, if there were any transfer, it would result in negative influence from Croatian due to false cognates between Croatian and other languages.

\section{Methodology}

\subsection{Participants}

The sample consisted of plurilingual learners who were at different ages with regard to the onset of learning foreign languages $(\mathrm{N}=106)$. They were secondary school learners of the first and second grades of grammar and vocational schools, whose mother tongue was Croatian (L1), L2/L3 English and Italian L2/L3, and L4 German. The years of language learning, especially between L2/L3 and L4 varied (9-10 years of learning English or Italian; 1-4 years of learning German).

\subsection{Assessments and Measures}

There were two elicitation tasks used for measuring positive and negative transfer in English vocabulary acquisition - translation of individual (decontextualized) words from Croatian into English read by the researcher in Croatian (Appendix 1); and translation of individual, contextualized words from Croatian into English, which were incorporated into the sentences in English (Appendix 3). The first task was partly based on the task used by De Angelis (2005), and the second on that used by Ecke (2001). Both tasks were adapted to our research. Each translation task was followed by the retrospective method in which learners were asked to express which of the suggested languages (Croatian, German or Italian) helped them translate the word into English, and thus because of which language they managed to translate a certain word (Appendices 2 and 4). All the instructions for each task were written in Croatian. Participants also completed a language learning background questionnaire that included information about the order of learning foreign languages, where and when learners started learning them, self-evaluation of proficiency in a particular language (including mother tongue), questions about exposure to the languages, psychotypology, affective motives, language aptitude and metalinguistic awareness. Variables like exposure to languages, psychotypology and learners' self-proficiency served as a helpful tool in determining the type of transfer. Psychotypology was measured by the question on the perception of similarity between English and the learners' other languages (Croatian, Italian, German). Learners' self-proficiency in each language was based on providing a rating (from 1-5) for the four language skills (listening, reading, speaking, writing) and general perception of their own knowledge in the languages, including their school grade, while exposure to languages consisted of questions on how often learners use each language outside the classroom for listening, reading, speaking, and writing, as well as for learning for school. 
Since "there is no consensus on the best measure of language proficiency, and self-ratings have received the most scrutiny" (Zhang, Dai, and Wang 2020, 5), we decided to assess learners' language proficiency using self-ratings.

The words that were explored in two translation tasks were cognates and false friends. In the first task there were nine true cognates in English and German (e.g., Eng. swim - Ger. schwimmen; Eng. bake - Ger. backen; Eng. milk - Ger. Milch), six true cognates in English, German and Italian (e.g., Eng. chemistry - Ger. Chemie - Ital. chimica), one partial cognate in English and German (e.g., Eng. sea - Ger. See), three false friends in English and German (e.g., Eng. rock - Ger. Rock) and one false friend in English and Italian (e.g., Eng. library Ital. libreria). In the second task there were five true cognates in English and German (e.g., Eng. apricot-Ger. Aprikose; Eng. uncle - Ger. Onkel), three true cognates in English, German and Italian (e.g., Eng. fever - Ger. Fieber - Ital. febbre), one true cognate in English and Italian (e.g., Eng. dictionary - Ger. dizionario), three partial cognates in English and German (e.g., Eng. fence - Ger. Fenster), nine false friends in English and German (e.g., Eng. bench - Ger. Bank; Eng. save - Ger. sparen) and three false friends in English, German and Italian (e.g., Eng. factory - Ger. Fabrik - Ital. fabbrica; Eng. family - Ger. familiär - Ital. familiare). It is important to point out that learners had been exposed to all the words that were used in the tasks, since they were taught in class as part of the regular curriculum throughout all learners' stages of language learning. Nevertheless, the words varied in their frequency of use in the classroom. To ascertain whether a particular word was high-, average- or low-frequency, we used the estimations of two English, two Italian and two German teachers, who had to mark on a list of words for a particular language which of the items they considered high-, averageor low-frequency in the learners' vocabulary in the classroom.

\subsection{Procedure}

The data collection was conducted during learners' regular English classes. First, learners were informed about the research and that their data would be strictly confidential. Since all the learners were older than 14, they gave their own written consent for participation in the research (according to the Code of Ethics for Research Involving Children that was published by the Croatian Council for Children in 2003). The number of learners varied, from 16 to 26 in each class. Before doing the two tasks aimed at investigating lexical transfer and filling out a language learning background questionnaire, the learners were introduced to the tasks and questionnaire by the researcher. The researcher also pointed out that their participation in the study was anonymous and that the data collected would be used exclusively for scientific purposes. Every participant received a booklet which included the tasks and questionnaire with written instructions in the Croatian language. First, the participants needed to read carefully the instructions for Task 1 in which they had to translate decontextualized words read aloud by the researcher in Croatian with an interval of 8-10 seconds between each word. After they did Task 1, the learners were asked to retrospect their translations from Task 1 by answering on a separate sheet of paper why they managed to translate a particular word, in such a way that they circled the given language that might have helped them in the translation (Croatian, German or Italian). Second, after retrospection the participants did Task 2, which consisted of the English sentences with underlined contextualized words that 
were written in Croatian and needed to be translated from Croatian into English. Then, after the completion of Task 2, the learners again engaged in retrospection, as in Task 1. The two tasks, each accompanied by the retrospective method, were undertaken by the participants within a 45-minute period. Additionally, the questionnaire was given to learners after the tasks, and the learners spent 20 minutes completing it.

All instances of transfer in the tasks were classified as lexical positive or negative transfer according to the cognates being investigated. The formal similarity in languages was analysed in terms of a similarity relation between the lemma in the background language (Croatian, German or Italian) that was the source of a particular instance of lexical transfer and a word in the target language (English).

In addition, manifestations of transfer were divided into two categories - subjective estimation of learners according to the retrospective method, and objective estimation - the one estimated by two independent evaluators, learners' answers about psychotypology and exposure to languages, both of which are described in the following section.

\subsection{Data Analysis}

The instances of transfer from German, Italian and Croatian were identified by learners' erroneous (negative transfer) or correct (positive transfer) word translation in English, and the frequency of each translation was entered into the statistical program IBM SPSS version 21.0. Based on descriptive statistics, the results were presented by using univariate analysis showing the distribution of positive and negative lexical transfer. The distribution was used as a typical and simple way of listing the number and percentages of participants in terms of positive and negative transfer from the background language into English.

We defined positive and negative transfer of a particular language on the basis of learners' self-estimation in the retrospective method, thus characterizing it as a subjective estimation in the analysis. Subjective estimation is defined here as learners' personal opinion of the positive or negative influence of one language item onto another. In contrast to subjective estimation, objective estimation was used only for determining negative transfer, because it was not affected by learners' explicit opinion of the transfer, but by the use of other multiple sources that reveal the nature of transfer (e.g., psychotypology, language self-proficiency, exposure to languages). As it was hard to determine negative transfer in some word translations (e.g., the use of the word public instead of audience in English), and what language was the source of such type of transfer (Croatian, German or Italian, e.g., Engl. public, Cro. publika; Ger. Publik; Ital. pubblico), in relation to objective estimation, we decided to use the estimation of the researcher, two independent evaluators, one for the German language, and one for Italian. The two evaluators did the estimation separately, and were used because they were highly proficient bilingual speakers of Croatian and German, and Croatian and Italian, and thus could easily note whether the transfer was from one of the languages.

The results of positive and negative lexical transfer manifestations presented in this paper are a part of author's unpublished $\mathrm{PhD}$ dissertation, and as such they are shown and discussed in the following section. 


\section{Results and Discussion}

This section brings the results based on data analysis of lexical transfer from three learners' languages - German, Italian and Croatian - indicating positive and negative transfer in English vocabulary production. The analysis is based on subjective and objective estimation for each language, presented in the tables with the numbers and percentages of participants in terms of negative and positive transfer from German, Italian and Croatian into English.

Since "cognates used for psycholinguistic experiments are traditionally rated by the experimenters themselves or are obtained in similarity rating studies using bilingual participants" (Letica Krevelj 2014, 106), using cognates in our study required a thorough exploration of lexical transfer from the source languages to the target language. Therefore, both subjective and objective estimation were needed to complement the results of positive and negative transfer. As learners' positive transfer in the study was measured by their selfreporting using the retrospective method on the facilitative effect of the source language on the target language and learners' correct answers in word translations, and negative transfer was measured by learners' self-reporting in the retrospective method on the hindering effect of the source language on the target language and the learners' erroneous answers, we referred to this type of judgment as subjective estimation, which in psycholinguistic studies has been assumed to reflect more accurate data.

In the cases where learners did not explicitly state the hindering effect of some words from the source language, and according to the learners' erroneous answer it was evident that it was a negative effect of one of the source languages, objective estimation was used (as described in section 4.4).

\subsection{Lexical Transfer from German as L4}

According to the results of subjective estimation, the German language had neither a negative nor positive influence for most of the learners, and less than $4 \%$ expressed negative transfer (Table 1). The exception was positive transfer of German in Task 1, where $8.4 \%$ participants estimated that German had a positive influence on English word translation in the same task (Table 2).

In relation to the objective estimation, there was a significant level of negative influence of German. This is seen in Table 2, where $25.5 \%$ of learners were influenced negatively by German in Task 1, and 45.3\% of them in Task 2.

TABLE 1. Numbers and percentages of participants in terms of positive and negative transfer from German into English with respect to subjective estimation $(\mathrm{N}=106)$.

\begin{tabular}{|c|c|c|c|c|c|c|c|}
\hline \multicolumn{7}{|c|}{ Subjective Estimation } \\
\hline \multicolumn{3}{|c|}{ Positive Transfer } & \multicolumn{4}{c|}{ Negative Transfer } \\
\hline \multicolumn{2}{|c|}{ Task 1} & \multicolumn{2}{|c|}{ Task 2} & \multicolumn{2}{c|}{ Task 1 } & \multicolumn{2}{c|}{ Task 2} \\
\hline $\mathbf{N}$ & $\%$ & $\mathbf{N}$ & $\%$ & $\mathbf{N}$ & $\%$ & $\mathbf{N}$ & $\%$ \\
\hline 9 & $8.4 \%$ & 2 & $1.9 \%$ & 3 & $2.8 \%$ & 4 & $3.8 \%$ \\
\hline
\end{tabular}


TABLE 2. Numbers and percentages of participants in terms of negative transfer from German into English with respect to objective estimation $(\mathrm{N}=106)$.

\begin{tabular}{|c|c|c|c|}
\hline \multicolumn{4}{|c|}{ Objective Estimation } \\
\hline \multicolumn{5}{|c|}{ Negative Transfer } \\
\hline $\mathbf{N}$ & Task 1 & $\mathbf{N}$ & Task 2 \\
\hline 27 & $25.5 \%$ & 48 & $\mathbf{\%}$ \\
\hline
\end{tabular}

Tables 1 and 2 show the numbers and percentages of participants in terms of positive and negative transfer from German into English with respect to subjective and objective estimations.

Overall, the first hypothesis (H1) was not confirmed. The German language did not demonstrate much negative influence on word translations, but instead positively influenced English word production. This may be attributed to the fact that the learners proficiency of German was estimated as high, and they were more engaged in learning German for school, rather than using it outside the classroom. The recency of some topics learned in both German and English classes might be the result of such a distribution of transfer.

Although the influence of German was more positive than negative, we identified more negatively than positively distributed words from German, which is shown in Table 3.

TABLE 3. Distribution of instances of negative lexical transfer from German based on word translations from Croatian into English in both tasks.

\begin{tabular}{|c|c|c|}
\hline Croatian word & Target English word & Answers \\
\hline more & sea & See \\
\hline zanimljiv & interesting & interesant \\
\hline talijanski & Italian & Italien, Italienish \\
\hline slobodno vrijeme & free time & Frei zeit \\
\hline kemija & chemistry & Chemie, Chemik \\
\hline blagajna & cash register & Case \\
\hline tvornica & factory & Fabric \\
\hline štedjeti & save & Fieber, Fiber \\
\hline vrućica & fever & Rent \\
\hline mirovina & retirement & Uncel, Unckle, Oncle, Unkle \\
\hline ujak & uncle & Bank, Banke \\
\hline klupa & bench &
\end{tabular}

Words that showed a positive effect from German into English were medicine, swim, free time, chemistry, year and milk.

\subsection{Lexical Transfer from Italian as L2/L3}

The results for the Italian language are different to those for German. The numbers and percentages of participants in terms of positive and negative transfer from Italian into English in subjective and objective estimations, respectively, are presented in Tables 4 and 5. 
TABLE 4. Numbers and percentages of participants in terms of positive and negative transfer from Italian into English with respect to subjective estimation $(\mathrm{N}=106)$.

\begin{tabular}{|c|c|c|c|c|c|c|c|}
\hline \multicolumn{7}{|c|}{ Subjective Estimation } \\
\hline \multicolumn{3}{|c|}{ Positive Transfer } & \multicolumn{4}{c|}{ Negative Transfer } \\
\hline \multicolumn{2}{|c|}{ Task 1} & \multicolumn{2}{|c|}{ Task 2} & \multicolumn{2}{|c|}{ Task 1 } & \multicolumn{2}{c|}{ Task 2} \\
\hline $\mathbf{N}$ & $\mathbf{\%}$ & $\mathbf{N}$ & $\mathbf{\%}$ & $\mathbf{N}$ & $\mathbf{\%}$ & $\mathbf{N}$ & $\%$ \\
\hline 44 & $41.5 \%$ & 10 & $9.4 \%$ & 14 & $13.1 \%$ & 14 & $13.1 \%$ \\
\hline
\end{tabular}

TABLE 5. Numbers and percentages of participants in terms of negative transfer from Italian into English with respect to objective estimation $(\mathrm{N}=106)$

\begin{tabular}{|c|c|c|c|}
\hline \multicolumn{3}{|c|}{ Objective Estimation } \\
\hline \multicolumn{3}{|c|}{ Negative Transfer } \\
\hline Task 1 & N & Task 2 \\
\hline $\mathbf{N}$ & $\mathbf{\%}$ & 23 & $21.7 \%$ \\
\hline 15 & $14.2 \%$ &
\end{tabular}

Most of the learners $(86.8 \%)$ were not affected by the negative influence of Italian on the English word production in either task entailing both subjective and objective estimation. However, the percentage of subjective estimation in terms of positive and negative transfer was considerably higher for Italian than for German.

The case is similar with the objective estimation of negative influence, but there was a lower percentage of Italian negative transfer than German. The positive transfer of Italian was more evident than that of German, especially for Task 1. Likewise, the results of the Italian language influence confirmed the second hypothesis (H2), as Italian had both positive and negative influences.

It seems that better knowledge of Italian and its frequent use have positive and negative influences at the same time. Therefore, the knowledge of Italian can sometimes facilitate, and sometimes hinder, English vocabulary acquisition, which might also be due to the years of learning the language as well as the exposure to it.

The positive influence of Italian was found for the following words: medicine, interesting, Italian, chemistry, audience, delicious, blankets, competition, serve, and family.

The negative influence of Italian was expressed in learners' erroneous answers for the words shown in the following table.

TABLE 6. Distribution of instances of negative lexical transfer from Italian based on word translations from Croatian into English in both tasks.

\begin{tabular}{|c|c|c|}
\hline Croatian word & Target English word & Answers \\
\hline knjižnica & library & bibliotace \\
\hline kemija & chemistry & kimic, chimic \\
\hline
\end{tabular}




\begin{tabular}{|c|c|c|}
\hline blagajna & cash register & casa, case \\
\hline tvornica & factory & fabric \\
\hline vrućica & fever & flue, fibre \\
\hline mirovina & retirement & pension \\
\hline gledateljstvo & audience & public \\
\hline klupa & bench & banco, bank \\
\hline
\end{tabular}

\subsection{Lexical Transfer from Croatian as L1}

As far as negative influence of Croatian is concerned, the results did not show any significant level of negative influence of Croatian in subjective estimation in Task 1 , as well as in objective estimation in Task 1. On the contrary, objective estimation of Croatian in Task 2 was slightly higher with regard to negative influence. Nonetheless, positive transfer was more obvious in subjective estimation in Task 1 than in Task 2.

Tables 7 and 8 show the numbers and percentages of participants in terms of positive and negative transfer from Croatian into English in subjective and objective estimations, respectively.

TABLE 7. Numbers and percentages of participants in terms of positive and negative transfer from Croatian into English with respect to subjective estimation $(\mathrm{N}=106)$.

\begin{tabular}{|c|c|c|c|c|c|c|c|}
\hline \multicolumn{7}{|c|}{ Subjective Estimation } \\
\hline \multicolumn{3}{|c|}{ Positive Transfer } & \multicolumn{4}{|c|}{ Negative Transfer } \\
\hline \multicolumn{2}{|c|}{ Task 1} & \multicolumn{2}{|c|}{ Task 2} & \multicolumn{2}{c|}{ Task 1} & \multicolumn{2}{c|}{ Task 2} \\
\hline $\mathbf{N}$ & $\mathbf{\%}$ & $\mathbf{N}$ & $\mathbf{\%}$ & $\mathbf{N}$ & $\mathbf{0}$ & $\mathbf{N}$ & $\mathbf{\%}$ \\
\hline 23 & $21.7 \%$ & 6 & $5.6 \%$ & 11 & $10.4 \%$ & 10 & $9.4 \%$ \\
\hline
\end{tabular}

TABLE 8. Numbers and percentages of participants in terms of negative transfer from Croatian into English with respect to objective estimation $(\mathrm{N}=106)$.

\begin{tabular}{|c|c|c|c|}
\hline \multicolumn{5}{|c|}{ Objective Estimation } \\
\hline \multicolumn{5}{|c|}{ Negative Transfer } \\
\hline $\mathbf{5}$ & Task 1 & $\mathbf{N}$ & Task 2 \\
\hline 9 & $8.4 \%$ & 35 & $32.9 \%$ \\
\hline
\end{tabular}

The results revealed that the third hypothesis (H3) was partly confirmed. The influence of Croatian in some cases indicated both positive and negative transfer. However, its manifestation was different across the two tasks, that is, Task 1 yielded more positive influences, while Task 2 more negative influences from Croatian. Less dominance of the Croatian language in our study might be to some extent due to learners' perception of Croatian and English as being typologically unrelated languages. 
Kopečková et al. $(2016,428)$ claim that due to the greater cognitive similarity between the $\mathrm{L} 3 / \mathrm{Ln}$ and the L2, rather than between the L3/Ln and the L1, L3/Ln, learners are expected to classify their native vs. foreign languages differently, and thus co-activate their non-native languages in subsequent language acquisition.

The Croatian language showed a positive effect for the words medicine, interesting, chemistry, unfriendly, milk, audience, serve, and family.

The negative effect of Croatian is noted in incorrectly written and translated words, as shown in Table 9.

TABLE 9. Distribution of instances of negative lexical transfer from Croatian based on word translations from Croatian into English in both tasks.

\begin{tabular}{|c|c|c|}
\hline Croatian Word & Target English Word & Answers \\
\hline stipendija & grant & stipendia, stipend \\
\hline klupa & bench & clupe \\
\hline blagajna & cash register & casse, case \\
\hline gledateljstvo & audience & public \\
\hline štedjeti & save & spare \\
\hline obiteljski & family & familary \\
\hline
\end{tabular}

In addition, the negative influence of Croatian was largely noted in words that are characterized as Croatian dialectal words, such as familijarni and fabrika, as well as Croatian loan words from German, such as kasa, šparati, and stipendija.

Generally, both positive and negative influences reflect the activation of all languages being used by the learners regardless of the level of proficiency in each language. As such, the results of this study are in line with the argument of Pfenninger and Singleton (2016, 169), who claim that "only a relatively low level of proficiency is required to have words from a language being activated and playing a role in the selection process". These earlier authors' study indicated that "after 2.5 years of French instruction, the participants' level of proficiency was high enough to have content words and inflections from French transferred" (Pfenninger and Singleton 2016, 169). The results also confirmed previous studies that showed a high activation of languages with low level of proficiency (Angelovska and Hahn 2012; Lindqvist and Bardel 2013).

The manifestations of transfer from the German language in the present study were most obvious in the production of true cognates, while both positive and negative transfer from the Italian language could be noted in the production of true cognates and false friends.

The interaction of the two languages in L3 production is also not excluded, especially when there is a formal similarity among all the three languages.

Evidently, a dynamic process of positive and negative transfer in English production depended on the language proficiency in both the source and target languages. 
In other words, the results showed that negative transfer was more obvious in learners with an average level of English proficiency and a high proficiency in the source language. Moreover, high proficiency in all the languages was the result of positive transfer, while low proficiency was the result of negative transfer. However, this study confirmed the results of Sercu (2007), indicating that positive transfer is more evident from better-mastered foreign languages, whereas negative transfer from less well-mastered languages.

Nevertheless, according to Ecke $(2015,154)$, 'multilinguals' access to vocabularies will fluctuate over time and inevitably include periods of stagnation, re-learning, and attrition of L2/L3 as well as L1 lexis".

Furthermore, many learners avoided translating the words. In addition to this, an avoidance strategy in studying the transfer is another crucial issue to be considered, and it is often referred to as a "covert transfer" (De Angelis 2005). The avoidance strategy was used by learners when they replaced the word translation with a word of a similar category: instead of landscape learners wrote fieldscape, area, background, country(side), environment, field, hometown, horis(z)on, nature, outdoors, panorama, place, scenery, sightview, valley, view; for apricot they used peach, pear, pineapple, raspberry, orange, cranberry, mandarin; instead of cake the words pastry, pie, sweets were used; instead of skirt learners wrote dress, shirt, shoes. We consider these words to be the result of avoidance because learners are sometimes afraid of making errors in the foreign language classroom, and in order to fill the gaps in language production they often use words of a similar category.

With regard to cognates, the results showed a facilitative effect of true cognates, but hindering effect of partial cognates and false friends. At the same time, we noticed that positive lexical transfer from German and Italian was more evident in high-frequency words, while negative lexical transfer was more characteristic for average- and low-frequency words in English.

Moreover, the interaction of all the languages in the plurilingual learners' language production has fully confirmed Dynamic Model of Multilingualism, as from the model's view "the behaviour of each individual language system in a multilingual system largely depends on the behaviour of previous and subsequent systems and it would therefore not make sense to look at the systems in terms of isolated development" (Herdina and Jessner 2002, 92).

\section{Conclusion}

To sum up, the study aimed at analysing positive and negative transfer in English vocabulary acquisition, based on the interactions of previously acquired (Croatian and Italian) and later acquired (German) languages. Some hypotheses were partly confirmed (H2 and $\mathrm{H} 3)$, and one hypothesis $(\mathrm{H} 1)$ was not confirmed. As the results demonstrate, the Italian language showed significant levels of both positive and negative transfer. However, there was not a significant level of positive or negative transfer from the Croatian language, but in some cases the Croatian language showed an influence that was both positive and negative. Moreover, the German language showed more positive than negative transfer.

It should be noted that the data gathered in present study cannot be generalized due to certain limitations. First, the sample was convenient, and heterogeneous regarding participants' 
language proficiency and exposure to languages. Moreover, the translation tasks that were used did not show a complete manifestation of positive and negative transfer, which might be due to decontextualized words and in some way due to Croatian loanwords from German, which could not be completely avoided in either task. In order to obtain more objective measures, future studies should apply different combinations of methods in observing the types and direction of lexical transfer, such as for example, using short text translation tasks from different language directions in combination with introspective or retrospective methods, as well as guided compositions in several learners' languages on the same topic accompanied by think-aloud protocols.

What should be further investigated are the cognitive aspects of experienced foreign language learners, as well as lexical processes in word retrieval in all the languages with reference to various stages of language learning. Likewise, a careful selection of cognates should be considered, especially in cases of possible first language dialects and borrowings from other languages, as in our example. We tried to avoid the influence of Croatian in the way that we did not use cognates in Croatian as a first language and other learners' languages, but the influence was manifested in the target language production because of the close connection of the first language selected vocabulary in the form of dialects, internationalisms and borrowings.

We may thus conclude that positive and negative transfer in the present study is more or less affected by learning-based factors, such as language proficiency, L2 status, recency of exposure and use of the languages; learner-based factors, such as psychotypology and metalinguistic awareness, motivation, and age; and language-based factors, like typological distance, degree of contact (borrowing), and type of writing systems.

Finally, there is still a need for further examinations of the nature of lexical transfer, especially in the context of lexicon-internal and lexicon-external factors. This means that except for lexicon-external factors, that are usually learner-, learning-, language- and event-based, investigations on lexical transfer should additionally take into account lexicon-internal factors, that are word-based, and which are of great significance for the English classroom.

In the future, the following glottodidactic implications for the English language classroom should be considered:

- transfer is a kind of strategy, and it can have more positive than negative effects on language learning (Ringbom 2007), so in the classroom it is essential to point to other languages known by the learners, especially those that belong to the same sub-group as the English language;

- teachers should also scaffold the use of other languages known by the learners, even if they do not belong to the same sub-group as the English language, in order to enhance learners' metalinguistic and cross-linguistic awareness;

- the errors that English learners are making in the production tasks are often due to either their wrong perception of the word they are using in the language or the lack of the overall proficiency in the language, so the teachers should use both receptive and productive tasks in developing communicative competence of the learners. 


\section{References}

Angelovska, Tanja, and Angela Hahn. 2012. "Written L3 (English): Transfer Phenomena of L2 (German) Lexical and Syntactic Properties." In Cross-Linguistic Influences in Multilingual Language Acquisition, edited by Danuta Gabryś-Barker, 23-40. Heidelberg: Springer. https://doi.org/10.1007/978-3-64229557-7_2.

Bardel, Camilla. 2015. "Lexical Cross-Linguistic Influence in Third Language Development." In Transfer Effects in Multilingual Language Development, edited by Hagen Peukert, 11-128. Amsterdam: John Benjamins. https://doi.org/10.1075/hsld.4.

Bardovi-Harlig, Kathleen, and Rex A. Sprouse. 2017. "Negative versus Positive Transfer." In The TESOL Encyclopedia of English Language Teaching, edited by John I. Liontas, 1-6. https://doi: 10.1002/9781118784235.eelt0084.

Boratyńska-Sumara, Joanna. 2014. "Lexical Transfer Research in Third Language Acquisition (TLA) - An Overview." Studia Linguistica Universitatis Iagellonicae Cracoviensis 131: 137-48. https://doi:10.4467 /20834624SL.14.007.2015.

Bouvy, Christine. 2000. “Towards the Construction of a Theory of Cross-Linguistic Transfer.” In English in Europe: The Acquisition of a Third Language, edited by Jasone Cenoz, and Ulrike Jessner, 143-56. Clevedon: Multilingual Matters.

Burton, Graham. 2012. "Cross-Linguistic Influence in Non-Native Languages: Explaining Lexical Transfer Using Language Production Models.” International Journal of Multilingualism 10 (1): 46-59. https:// doi.org/10.1080/14790718.2012.679274.

De Angelis, Gessica. 2005. "Multilingualism and Non-native Lexical Transfer: An Identification Problem." International Journal of Multilingualism 2 (1): 1-25. https://doi.org/10.1080/17501220508668374.

—. 2007. Third or Additional Language Acquisition. Bristol: Multilingual Matters.

Dewaele, Jean-Marc. 1998. "Lexical Inventions: French Interlanguage as L2 versus L3.” Applied Linguistics 19: 471-90. https://doi.org/10.1093/applin/19.4.471.

Ecke, Peter. 2001. "Lexical Retrieval in a Third Language: Evidence from Errors and Tip-of-the-Tongue States." In Cross-Linguistic Influence in Third Language Acquisition: Psycholinguistic Perspectives, edited by Jasone Cenoz, Britta Hufeisen, and Ulrike Jessner, 90-114. Bristo: Multilingual Matters.

—. 2015. "Parasitic Vocabulary Acquisition, Cross-Linguistic Influence, and Lexical Retrieval in Multilinguals." Bilingualism: Language and Cognition 18 (2): 145-62. https:// doi.org/10.1017/S1366728913000722.

Efeoglu, Gulumser, H. Gülru Yüksel, and Suat Baran. 2020. "Lexical Crosslinguistic Influence: A Study of Three Multilingual Learners of L3 English.” International Journal of Multilingualism 17 (4): 535-51. https://doi.org/10.1080/14790718.2019.1620239.

Fuster, Carles, and Hannah Neuser. 2020. "Exploring Intentionality in Lexical Transfer." International Journal of Multilingualism 17 (4): 516-34. https://doi.org/10.1080/14790718.2018.1559845.

Gabryś, Danuta. 2000. "The Phenomenon of Transfer in L3 Learning from a Psycholinguistic Perspective: A Case Study." Psycholinguistics on the Threshold of the Year 2000, 409-13. http:// ler.letras.up.pt/uploads/ficheiros/8460.pdf.

Gabryś-Barker, Danuta. 2006. "The Interaction of Languages in the Lexical Search of Multilingual Language Users." In Cross-Linguistic Influences in the Second Language Lexicon, edited by Janusz Arabski, 144-66. Clevedon: Multilingual Matters.

Gibson, Martha, and Britta Hufeisen. 2003. "Investigating the Role of Prior Foreign Language Knowledge." In The Multilingual Lexicon, edited by Jasone Cenoz, Britta Hufeisen, and Ulrike Jessner, 87-102. New York: Kluwer Academic Publishers. https://doi.org/10.1007/b101932.

Herdina, Philip, and Ulrike Jessner. 2002. A Dynamic Model of Multilingualism. Bristol: Multilingual Matters.

Herwig, Anna. 2001. "Plurilingual Lexical Organisation: Evidence from Lexical Processing in L1-L2L3-L4 Translation." In Cross-Linguistic Influence in Third Language Acquisition: Psycholinguistic Perspectives, edited by Jasone Cenoz, Britta Hufeisen, and Ulrike Jessner, 115-37. Bristol: Multilingual Matters. 
Ilomaki, Anu. 2005. "Cross-Linguistic Influence: A Cross-Sectional Study with Particular

Reference to Finnish-Speaking and English-Speaking Learners of German.” http://

www.scss.tcd.ie/undergraduate/bacsll/bacsll_web/anu_ilomaki0405.pdf.

Jarvis, Scott, and Aneta Pavlenko. 2008. Crosslinguistic Influence in Language and Cognition. New York: Routledge Taylor \& Francis Group.

Jarvis, Scott. 2009. "Lexical Transfer." In The Bilingual Mental Lexicon. Interdisciplinary Approaches, edited by Aneta Pavlenko, 99-124. Bristol: Multilingual Matters.

Kopečková, Romana, Marta Marecka, Magdalena Wrembel, and Ulrike Gut. 2016. "Interactions between Three Phonological Subsystems of Young Multilinguals: The Influence of Language Status." International Journal of Multilingualism 13 (4): 426-43. https://doi.org/10.1080/14790718.2016.12 17603.

Kujalowicz, Agnieszka, and Ewa Zajdler. 2009. "Language Activation and Lexical Processing by Polish Learners of English and Chinese - The Role of Learning Experience in TLA." International Journal of Multilingualism 6 (1): 85-104. https://doi.org/10.1080/14790710802207570.

Larsen-Freeman, Diane, and Michael H. Long. 1991. An Introduction to Second Language Acquisition Research. London: Taylor \& Francis.

Latkowska, Jolanta. 2006. "On the Use of Translation in Studies of Language Contact." In Cross-Linguistic Influences in the Second Language Lexicon, edited by Janusz Arabski, 210-25. Clevedon: Multilingual Matters.

Letica, Stela, and Sandra Mardešić. 2007. "Cross-Linguistic Transfer in L2 and L3 Production." In UPRT 2007: Empirical Studies in English Applied Linguistics, edited by Joseph Horváth, and Marianne Nikolov, 307-18. Pécs: Lingua Franca Csopor.

Letica Krevelj, Stela. 2014. "Cross-Linguistic Interaction in Acquiring English as L3: Role of Psychotypology and L2 Status." PhD diss, University of Zagreb.

Lindqvist, Christina. 2009. "The Use of the L1 and the L2 in French L3: Examining Cross-Linguistic Lexemes in Multilingual Learners' Oral Production.” International Journal of Multilingualism 6 (3): 281-97. https://doi.org/10.1080/14790710902812022.

Lindqvist, Christina, and Camilla Bardel. 2013. "Exploring the Impact of the Proficiency and Typology Factors: Two Cases of Multilingual Learners' L3 Learning." In Essential Topics in Applied Linguistics and Multilingualism: Studies in Honour of David Singleton, edited by Miroslaw Pawlak and Larissa Aronin, 253-66. Heidelberg: Springer. https://doi.org/10.1007/978-3-319-01414-2_15.

Makarova Tominec, Irina. 2015. "Ruščina in slovenščina: jezikovna odstopanja v ruščini pod vplivom slovenščine kot jezika okolja.” Jezikoslovni zapiski 21 (2): 159-89. https:// doi.org/10.3986/JZ.21.2.6898.

Ortega, Mireia, and M. Luz Celaya. 2019. "Lexical Crosslinguistic Influence and Study Abroad: Do Learners Use L1-Based Resources Less?” Languages 4 (55): 1-9. https:// doi.org/10.3390/languages4030055.

Pál, Andrea. 2000. "The Role of Cross-Linguistic Formal Similarity in Hungarian-German Bilingual Learners of English as a Foreign Language.” PhD diss., University of Potsdam. https://dnb.info/963210610/34.

Perić, Barbara, and Sonja Novak Mijić. 2017. "Cross-Linguistic Influences in Third Language Acquisition (Spanish) and the Relationship between Language Proficiency and Types of Lexical Errors." Croatian Journal of Education 19 (2): 91-107. https://doi.org/10.15516/cje.v19i0.2619.

Peukert, Hagen. 2015. “Transfer Effects in Multilingual Language Development." In Transfer Effects in Multilingual Language Development, edited by Hagen Peukert, 1-17. Amsterdam: John Benjamin. https://doi.org/10.1075/hsld.4.

Pfenninger, Simone E., and David Singleton. 2016. "Age of Onset, Socio-Affect and Cross-Linguistic Influence: A Longterm Classroom Study.” Vigo International Journal of Applied Linguistics 13: 147-79.

Pinto, Jorge. 2013. "Cross-Linguistic Influence at Lexical Level. A Study with Moroccan Learners of Portuguese as an L3/LN.” Revista Nebrija de Lingüistica Aplicada 12: 3-50.

Ringbom, Håkan. 2007. Cross-Linguistic Similarity in Foreign Language Learning. Bristol: Multilingual Matters. 
Sercu, Lies. 2007. "Acquiring Multilingualism at School. What Translation Tasks Tell Us about

Adolescents' Use of the Multilingual Lexicon." International Journal of Multilingualism 4 (1): 523-75. https://doi.org/10.2167/ijm056.0.

Tkachenko, Nadezda. 2011. "The Relative Influence of English (L2) vs. Russian (L1) on the Translation from Swedish (L3) into Russian Depending on Proficiency in L3.” Master's Thesis, Lund University. http://lup.lub.lu.se/luur/download?func=downloadFile\&recordOId=2545119\&fileOId=2545139.

Tymczyńska, Maria. 2012. "Trilingual Lexical Processing in Online Translation Recognition. The Influence of Conference Interpreting Experience." In Cross-Linguistic Influences in Multilingual Language Acquisition, edited by Danuta Gabryś-Barker, 151-67. Berlin: Springer. https://doi.org/10.1007/9783-642-29557-7.

Williams, Sarah, and Bjorn Hammarberg. 1998. "Language Switches in L3 Production: Implications for a Polyglot Speaking Model.” Applied Linguistics 19 (3): 295-33. https:// doi.org/10.1093/applin/19.3.295.

Woll, Nina. 2016. "The Role of Metalinguistic Awareness and of L2 Proficiency in Positive Lexical Transfer from English (L2) to German (L3) by French Speaking Quebeckers." PhD diss., Univeresité Laval. https://corpus.ulaval.ca/jspui/handle/20.500.11794/26923.

Zhang, Huiyu, Ying Dai, and Yingchong Wang. 2020. "Motivation and Second Foreign Language Proficiency: The Mediating Role of Foreign Language Enjoyment." Sustainability 12 (1302): 1-13. https://doi.org/10.3390/su12041302.

\section{Appendix 1: Task 1 (English Version) INSTRUCTIONS FOR TASK 1}

In this task you will carefully listen to the words in Croatian read by the researcher, and you will automatically translate them into English, by writing each word (or word phrase) next to the number in order.

The researcher will read the words within an interval of 8-10 seconds or even less, depending on the completion of the task by most of the learners in the classroom.

During your writing, you must not return to the previously written or unwritten word (or word phrase), but focus on the next word being read by the researcher. Use your knowledge and do not ask for help your friends, and do not think aloud!

\section{Provide a word translation even if you are not sure in its correctness!}

While doing the task, DO NOT DIRECT ADDITIONAL QUESTIONS to the researcher, your friend or teacher in the classroom.

By doing this task you will help the researcher in the implementation of the study. Thank you for understanding.

1.

2.

3. .... 


\section{Appendix 2: Retrospective Method After Task 1 (English Version)}

Read the following words which you were translating in the previous task from Croatian into English, and for each word mark the statement that refers to you.

\section{MANAGED TO TRANSLATE THE WORD ...}

\section{1. kolač}

a) ... because I knew the word from learning English b)... because of German c)... because of Italian d)... because of Croatian e) something else (state)

\section{2. lijek}

a) ... because I knew the word from learning English b)... because of German c)... because of Italian d)... because of Croatian e) something else (state)

\section{3. krajolik}

a) ... because I knew the word from learning English b)...because of German c)... because of Italian d)... because of Croatian e) something else (state)

\section{4. more}

a) ... because I knew the word from learning English b)... because of German c)... because of Italian d)... because of Croatian e) something else (state)

\section{5. zanimljiv}

a) ... because I knew the word from learning English b)...because of German c)... because of Italian d)... because of Croatian e) something else (state)

\section{6. knjižnica}

a) ... because I knew the word from learning English b)...because of German c)... because of Italian d)... because of Croatian e) something else (state)

\section{7. mišljenje}

a) ... because I knew the word from learning English b)...because of German c)... because of Italian d)... because of Croatian e) something else (state)

\section{8. cijena}

a) ...because I knew the word from learning English b)... because of German c)... because of Italian d)... because of Croatian e) something else (state)

\section{9. suknja}

a) ... because I knew the word from learning English b)... because of German c)... because of Italian d)... because of Croatian e) something else (state) 


\section{0. plivati}

a) ... because I knew the word from learning English b)... because of German c)... because of Italian d)... because of Croatian e) something else (state)

\section{1. talijanski}

a) ...because I knew the word from learning English b)...because of German c)... because of Italian d)... because of Croatian e) something else (state)

\section{2. ljetni praznici}

a) ... because I knew the word from learning English b)...because of German c)... because of Italian d)... because of Croatian e) something else (state)

\section{3. glasan}

a) ... because I knew the word from learning English b)...because of German c)... because of Italian d)... because of Croatian e) something else (state)

\section{4. slobodno vrijeme}

a) ... because I knew the word from learning English b)...because of German c)... because of Italian d)... because of Croatian e) something else (state)

\section{5. kemija}

a) ... because I knew the word from learning English b)... because of German c)... because of Italian d) ... because of Croatian e) something else (state)

\section{6. vremenski točan}

a) ...... because I knew the word from learning English b)... because of German c)... because of Italian d)... because of Croatian e) something else (state)

\section{7. peći (kolač)}

a) ... because I knew the word from learning English b)...because of German c)... because of Italian d) ... because of Croatian e) something else (state)

\section{8. neprijateljski}

a) ... because I knew the word from learning English b)... because of German c)... because of Italian d)... because of Croatian e) something else (state)

\section{9. godina}

a) ... because I knew the word from learning English b)... because of German c)... because of Italian d)... because of Croatian e) something else (state)

\section{0. mlijeko}

a) ... because I knew the word from learning English b)...because of German c)... because of Italian d)... because of Croatian e) something else (state) 


\section{Appendix 3: Task 2 (English Version)}

\section{INSTRUCTIONS FOR TASK 2}

Read each sentence in English and then translate the underlined word above the sentence from Croatian into English by filling it out in the sentence.

Try to translate the words even if you are not completely sure how the word is written. Write the first translation that comes to your mind and DO NOT RETURN TO THE ALREADY WRITTEN OR NON-WRITTEN WORD!

\section{1. blagajna}

When I came to the shop, there was a queue of people waiting at the

2. pekara

My friend has bought some cakes in the at the corner of the street.

\section{3. tvornica}

My father works in a that employs hundreds of people.

\section{4. šstedjeti}

You should a lot for a new car.

\section{5. marelica}

Do you like juice?

\section{6. vrućica}

She caught a on her travels in Africa, and hardly survived.

\section{7. neuspjeh}

The whole thing was a complete

\section{8. mirovina}

Susan is going to take early

\section{9. gledateljstvo}

The was clapping for 10 minutes.

10. ukusan

This new restaurant is well known for its cuisine.

\section{1. ograda}

In agriculture, is used to keep animals in or out of an area.

\section{2. ujak}

Last year I visited my in Germany. 


\section{3. mjesec}

Every she visits her grandparents.

\section{4. pokrivači}

The shop sells beautiful bed

\section{5. natjecanje}

There is now intense between schools to attract students.

\section{6. novčana potpora}

She won a to study at Stanford.

\section{7. posluživati}

Pour the sauce over the pasta and immediately.

\section{8. klupa}

When it is nice weather my grandmother often walks in the park and sits on a

\section{9. obiteljski}

The Smiths have opened a business.

\section{0. mahati}

Why did you to him?

\section{1. primiti}

He is going to an award for bravery.

\section{2. mladež}

The fight was started by a gang of the

\section{3. srednja škola}

My brother and I went to the same

24. rječnik

A __explains the meaning of words in alphabetical order.

\section{5. džeparac}

My parents often give me some when I go out. 


\section{Appendix 4: Retrospective Method After Task 2 (English Version)}

Read the following words which you were translating in the previous task from Croatian into English, and for each word mark the statement that refers to you.

\section{MANAGED TO TRANSLATE THE WORD ...}

\begin{tabular}{|c|c|}
\hline $\begin{array}{l}\text { 1. blagajna } \\
\text { a)... because I knew the word from learning English b)...because of German } \\
\text { d)... because of Croatian e) something else (state) }\end{array}$ & c) $\ldots$ because of Italian \\
\hline $\begin{array}{l}\text { 2. pekara } \\
\text { a)... because I knew the word from learning English b)... because of German } \\
\text { d)... because of Croatian e) something else (state) }\end{array}$ & c)... because of Italian \\
\hline $\begin{array}{l}\text { 3. tvornica } \\
\text { a) ... because I knew the word from learning English b)... because of German } \\
\text { d)... because of Croatian e) something else (state) }\end{array}$ & c)... because \\
\hline $\begin{array}{l}\text { 4. štedjeti } \\
\text { a) ... because I knew the word from learning English b)... because of German } \\
\text { d)... because of Croatian e) something else (state) }\end{array}$ & alian \\
\hline $\begin{array}{l}\text { 5. marelica } \\
\text { a) ... because I knew the word from learning English b)... because of German } \\
\text { d) ... because of Croatian e) something else (state) }\end{array}$ & c)... because of Italian \\
\hline $\begin{array}{l}\text { 6. vrućica } \\
\text { a) ... because I knew the word from learning English b)... because of German } \\
\text { d)... because of Croatian e) something else (state) }\end{array}$ & c)... because of Italian \\
\hline $\begin{array}{l}7 . \text { neuspjeh } \\
\begin{array}{l}\text { a) ... because I knew the word from learning English b)... because of German } \\
\text { d)... because of Croatian e) something else (state) }\end{array}\end{array}$ & c)... because of Italian \\
\hline $\begin{array}{l}\text { 8. mirovina } \\
\begin{array}{l}\text { a) ... because I knew the word from learning English b)... because of German } \\
\text { d)... because of Croatian e) something else (state) }\end{array}\end{array}$ & c)... because of Italian \\
\hline $\begin{array}{l}\text { 9. gledateljstvo } \\
\text { a) ... because I knew the word from learning English b)... because of German } \\
\text { d)... because of Croatian e) something else (state) }\end{array}$ & c)... because of Italian \\
\hline $\begin{array}{l}\text { 10. ukusan } \\
\text { a) ... because I knew the word from learning English b)... because of German } \\
\text { d)... because of Croatian e) something else (state) }\end{array}$ & c)... because of Italian \\
\hline
\end{tabular}




\section{1. ograda}

a) ... because I knew the word from learning English b)... because of German c)... because of Italian d)... because of Croatian e) something else (state)

\section{2. ujak}

a) ... because I knew the word from learning English b)...because of German c)... because of Italian d)... because of Croatian e) something else (state)

\section{3. $\underline{\text { mjesec }}$}

a) ... because I knew the word from learning English b)...because of German c)... because of Italian d)... because of Croatian e) something else (state)

\section{4. pokrivači}

a) ... because I knew the word from learning English b)...because of German c)... because of Italian d)... because of Croatian e) something else (state)

\section{5. natjecanje}

a) ... because I knew the word from learning English b)...because of German c)... because of Italian d)... because of Croatian e) something else (state)

\section{6. novčana potpora}

a) ... because I knew the word from learning English b)... because of German c)... because of Italian d)... because of Croatian e) something else (state)

\section{7. posluživati}

a) ... because I knew the word from learning English b)...because of German c)... because of Italian d)... because of Croatian e) something else (state)

\section{8. klupa}

a) ... because I knew the word from learning English b)...because of German c)... because of Italian d)... because of Croatian e) something else (state)

\section{9. obiteljski}

a) ... because I knew the word from learning English b)...because of German c)... because of Italian d)... because of Croatian e) something else (state)

\section{0. mahati}

a) ... because I knew the word from learning English b)... because of German c)... because of Italian d)... because of Croatian e) something else (state)

\section{1. primiti}

a) ... because I knew the word from learning English b)... because of German c) ... because of Italian d)... because of Croatian e) something else (state) 


\section{2. mladež}

a) ... because I knew the word from learning English b)... because of German c)... because of Italian d)... because of Croatian e) something else (state)

\section{3. srednja škola}

a) ... because I knew the word from learning English b)... because of German c)... because of Italian d)... because of Croatian e) something else (state)

\section{4. rječnik}

a) ... because I knew the word from learning English b)...because of German c)... because of Italian d)... because of Croatian e) something else (state)

\section{5. džeparac}

a) ... because I knew the word from learning English b)... because of German c)... because of Italian d)... because of Croatian e) something else (state) 